\title{
Prioritization of Crop Residues for Improving Productivity on Smallholder Dairy Farming Households in the Lake Victoria Crescent, Uganda
}

\author{
Andrew Mwebaze Atuhaire1, Swidiq Mugerwa ${ }^{1}$, Samuel Okello $^{2 *}$, Kenneth Okello Lapenga ${ }^{2}$, \\ Fred Kabi ${ }^{3}$, Jolly Mary Kabirizi ${ }^{1}$ \\ ${ }^{1}$ National Agricultural Research Institute (NARO), National Livestock Resources Research Institute (NaLIRRI), \\ Tororo, Uganda \\ ${ }^{2}$ Department of Livestock and Industrial Resources, College of Veterinary Medicine, Animal Resources and \\ Bio-Security, Makerere University, Kampala, Uganda \\ ${ }^{3}$ Department of Agricultural Production, College of Agricultural and Environmental Sciences, Makerere \\ University, Kampala, Uganda \\ Email: sokello@covab.ma.ac.ug
}

Received 22 January 2014; revised 25 February 2014; accepted 4 March 2014

Copyright (C) 2014 by authors and Scientific Research Publishing Inc.

This work is licensed under the Creative Commons Attribution International License (CC BY).

http://creativecommons.org/licenses/by/4.0/

\section{(c) (i) Open Access}

\begin{abstract}
Poor nutrition has been identified as a major constraint to productivity in smallholder dairy farming households in Uganda, particularly in Lake Victoria Crescent Agro-ecological Zone (LVZ). Clarification on nutritional potential of crop residues is central to formulation of sustainable dairy cattle nutrition strategies. Data were collected from 126 randomly selected respondents using structured and semi-structured questionnaires. Farmers' responses on crop residues utilization, handling, limitations, spatial and temporal variability were collected. Kruskal-Wallis test showed significant differences on utilization of available crop residues $\left(X^{2}=50.4, \mathrm{df}=4, \mathrm{p}=0.0001\right)$ among farmer's rankings. It was established that maize stovers were major crop residues utilized and inadequate knowledge to process crop residues was ranked as a major limitation. The study provided basic information on the importance of crop residues. Further research studies should focus on improving the nutritive value of maize stover.
\end{abstract}

\section{Keywords}

Haulms; Stovers; Nutritive Value; Vine

\footnotetext{
"Corresponding author.
}

How to cite this paper: Atuhaire, A.M., et al. (2014) Prioritization of Crop Residues for Improving Productivity on Smallholder Dairy Farming Households in the Lake Victoria Crescent, Uganda. Open Journal of Animal Sciences, 4, 103-111. 


\section{Introduction}

Because of its contribution to the socio-economic development of rural Uganda in both food security and income generation, especially, among women and other disadvantaged groups, smallholder dairy production system has received considerable support from the Government of Uganda as well as non-government organizations [1]. Moreover, by functioning as a store of wealth [2] and supplying manure for crop production [3], dairy cattle fit very well in integrated crop-livestock systems. In Uganda, dairy cattle play a key role in the nutrition, of most households with per capita milk consumption of about 58 litres [4] against FAO requirement of 200 litres per person per year [5]. While annual average milk yield per cow per lactation per year of 305 days in developed countries can go above $8000 \mathrm{~kg}$, less than $2000 \mathrm{~kg}$ is obtainable from pure dairy breeds, 1000 from cross breeds and $500 \mathrm{~kg}$ from indigenous cows in Uganda [6]. These statistics are obviously distressing in light of the rapidly growing human population at a rate of 3.2\% annually [7]. In [8] it is singled out that feed scarcity leads to poor nutrition which is a key constraint holding down production efficiency and health of the dairy cow on smallholder dairy farms in Lake Victoria Agro-ecological Zone (LVZ). Poor nutrition of dairy cattle is exaggerated by drought induced feed scarcity attributed partly to change in climate and demographics. As human population increases demand for milk also increases, crop production expands, availability of land for forage production decreases contributing towards dairy cattle feed scarcity. With projected increase in demand for milk, coupled with declining land size for forage production due to demographic pressure, it seems inevitable for farmers to embrace alternative feed resources. Utilization of crop residues therefore seems a logical alternative to address the escalating levels of feed scarcity among smallholder dairy farming systems [9]. Efficient utilization of crop residues however faces a number of intriguing challenges that include low levels of metabolized energy and crude protein [10] seasonal variability [11], bulky [12] and poor keeping qualities [13]. These challenges should be acknowledged for appropriate technological innovations that prioritise crop residues as alternative feed to supply nutrients to dairy cattle for improved productivity on smallholder farm.

Crop residues have been used as livestock feeds since time immemorial and are readily available feed resources [14], however their nutritional value is poor and well documented [10] [15]. Considerable research efforts have been devoted into improving their nutritional value through crop management and breeding, physical, biological and chemical treatments as well as supplementation with high protein oil cakes, green fodder, and tree leaves [8] [15]. However, on-farm implementations of these strategic innovations seem unsatisfactory. Furthermore, in Uganda there is scanty of information on crop residue utilization, temporal and spatial variability as well as limitations associated with utilization on smallholder dairy farms unlike in other developing countries. Which make a basis in identifying opportunities, to priorities feeds from crop residues for improved nutrition that translate into enhanced productivity on smallholder dairy farming household. Thus this survey was designed to assess crop residues variability, limitations and opportunities in LVZ for future research on developing appropriate dairy feeding systems that utilize crop residues. These will in long run secure smallholder dairy farming from demographic pressure and substance farming to improved productivity and sustainable farming system.

\section{Materials and Methods}

\subsection{Description of the Study Area}

The study was conducted in the Lake Victoria Agro-ecological Zone of Uganda which hosts the majority of smallholder dairy farmers. Three districts namely Buikwe $\left(0^{\circ} 18^{\prime} 4 " \mathrm{~N}\right.$ and $\left.33^{\circ} 3^{\prime} 6^{\prime \prime} \mathrm{E}\right)$, Jinja $\left(0^{\circ} 25^{\prime} 28^{\prime \prime} \mathrm{N}\right.$ and $\left.33^{\circ} 12^{\prime} 15^{\prime \prime} \mathrm{E}\right)$ and Mayuge $\left(0^{\circ} 27^{\prime} 35^{\prime \prime} \mathrm{N}\right.$ and $\left.33^{\circ} 28^{\prime} 49^{\prime \prime} \mathrm{E}\right)$ were selected for the study based on the intensity of smallholder dairy farms (Figure 1). The mean daily temperature ranges between $16^{\circ} \mathrm{C}-28^{\circ} \mathrm{C}, 18^{\circ} \mathrm{C}-28^{\circ} \mathrm{C}$ and $17^{\circ} \mathrm{C}-27^{\circ} \mathrm{C}$ for Buikwe, Jinja and Mayuge Districts. The mean annual rainfall ranges between 1279 to $1544 \mathrm{~mm}$, 1200 to $1500 \mathrm{~mm}$ and 1100 to $1500 \mathrm{~mm}$ for Jinja, Mayuge and Buikwe respectively. The districts experience a tropical climate bimodal rainfall pattern characterized by two rainy seasons (March to May and September to November) with dry spells (December to February and June to August). According to the Population and Housing Census (2002), the estimated mean population density was 256, 658, and 92.55 persons $\mathrm{km}^{-2}$ for Buikwe, Jinja and Mayuge respectively. Agriculture is the main economic activity, prolonged droughts that lead to crop failure and increased feed scarcity is the main constraints to agricultural production.

Dairy cattle are mainly raised under intensive and semi-intensive smallholder management systems with ma- 


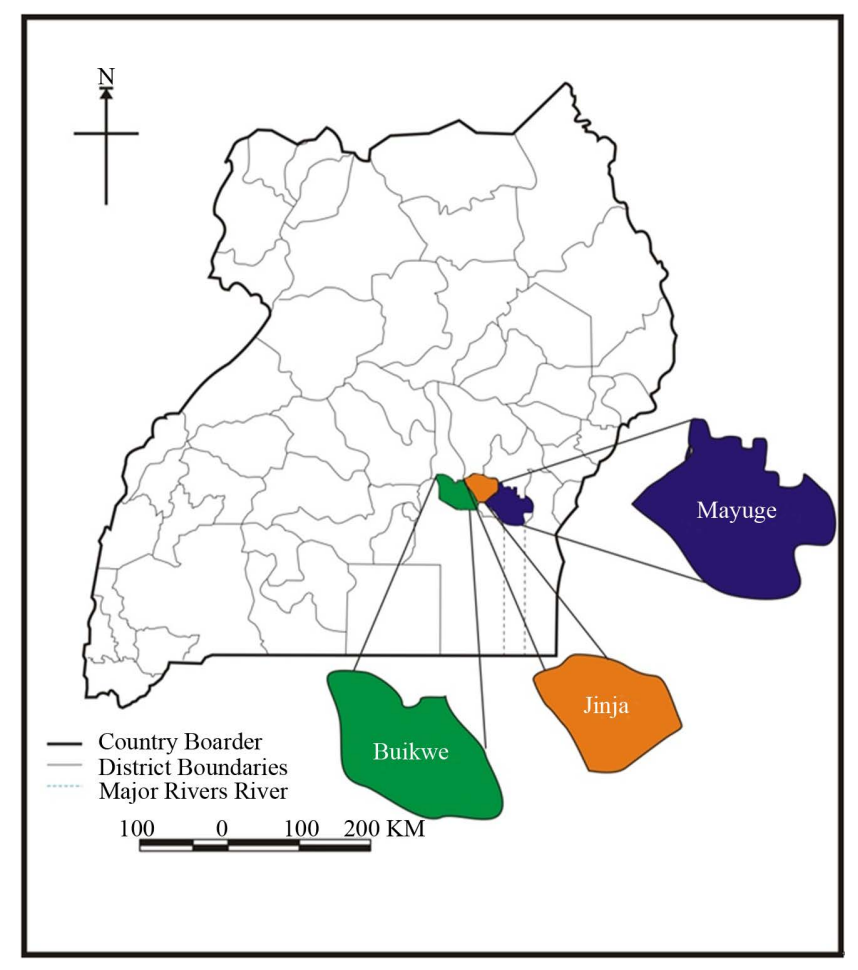

Figure 1. Map of Uganda showing the location of Buikwe, Jinja and Mayuge districts.

jority of farmers keeping between 1 to 5 head of cattle under stall feeding with negligible grazing and tethering. The mean agricultural area is 529, 601.1 and $603.3 \mathrm{~km}^{2}$ for districts of Buikwe, Jinja and Mayuge respectively.

\subsection{Sampling Procedure, Sample Size, Data Collection and Analysis}

The study was conducted in three districts (Buikwe, Mayuge and Jinja) which were purposively selected based on the intensity of smallholder dairy farms. Three sub-counties were randomly selected from each district. After consultations with the district extension staff and sub-county extension officers and following all procedures of systematic random sampling selection, fourteen respondents were selected from each sub-county totaling to forty two respondents per district. Data was obtained using pre-tested structured and semi-structured questionnaires administered by way of one-on-one direct interviews. Focus group discussions (one per sub-county) were held to corroborate the information gathered in direct interviews. The questionnaires and focus group discussions were intended to capture information on availability, variability and limitations to utilize crop residues on smallholder dairy farms.

In order to establish if there were statistical significance among farmers' ranking of crop residues utilization, variability and limitations in utilization of crop residues, farmers' responses were pooled and subjected to nonparametric statistics analysis (Kruskal-Wallis one-way analysis of variance) using [16]. Five crop residues were ranked by farmers using a scale of 1 to 5 with five being the most important crop residue. Also, five limiting factors were ranked by farmers using a scale of 1 to 5 , with 5 being the most important limitation in utilization of crop residue. The computed sum of ranks and mean of ranks were compared using multiple pair-wise comparisons to establish if there were significant differences in utilization levels and limitations to utilization of crop residues. [16] was used to generate summary statistics (frequencies, percentages and means) for the variables and later tabulated.

\section{Results}

\subsection{Farmers' Ranking on Utilization of Crop Residues}

Kruskal-Wallis test showed that there were significant differences $(\mathrm{p}=0.0001)$ maintained in all the districts 
among farmers' ranking of the different crop residues (Table 1). Farmers' ranking on utilization of maize stover was highest throughout the zone, in Buikwe, Jinja and Mayuge with mean ranks of 168.48, 122.67 and 152.15 respectively.

Farmers ranked maize stover (mean of ranks $=152.15,122.67$ and 168.48) and sweet potato vines (mean of ranks $=117.32,121.65$ and 124.42) as the most important crop residue throughout Mayuge, Jinja and Buikwe districts respectively. Sugar cane tops (mean of ranks $=64.56$ and 80.37) were ranked as the least important crop residue in Buikwe and Mayuge districts while in Jinja ground nuts haulms (mean of ranks $=69.75$ ) was ranked as the least important crop residue. In Mayuge district, ground nut haulms (mean of ranks $=84.52$ ) were ranked second least important crop residue while in Jinja it was sugar cane tops (mean of ranks $=86.7$ ) and in Buikwe it was banana peels (mean of ranks $=89.33$ ).

\subsection{Farmers' Ranking on Spatial and Temporal Variability of Crop Residues}

Spatial and temporal variability of crop residues in the study area were assessed on monthly basis by asking the respondents to classify abundance of crop residues as highest, moderate or lowest. The orders were then converted to scores in such ways that score 3 was given to the highest in abundance, score 2 moderate and score 1 lowest. Then the percentage score for each crop residue was calculated as its total weighted score divided by the overall total scores. Calculated accordingly, the percent score for variability of crop residues at given point in time by respondents are given in Figure 2 [7], characterizes seasons based on amount of rain fall received, prevailing humidity and temperature. LVZ has two dry seasons (December to February and June to August) and two wet seasons (March to May and September to November) in a year. Generally farmers score indicated that quantities of crop residues vary throughout the year. The highest in abundance was reported to occur towards the beginning of dry season and least abundant levels were reported to be at the end of dry season. Maize stover was scored highest in abundance in first season, reduces slightly in second season then attains peak abundance in third season and reduces progressively in fourth season throughout the zone. The abundance levels of sweet potato vines were scored highest in first season reduces in second season, increases progressively to attain its peak abundance in third season, in fourth season it moves down then starts increasing again towards the end of the

\begin{tabular}{|c|c|c|c|c|}
\hline & Crop residue & Sum of ranks & Mean of ranks & (Chi' ${ }^{2}$ df, p-value) \\
\hline \multirow{5}{*}{ Mayuge } & Sugar cane tops & 2647.00 & $64.56^{\mathrm{a}}$ & \multirow{5}{*}{$\begin{array}{c}\mathrm{X}^{2}=54.40 \\
\mathrm{df}=4 \\
\mathrm{p}=0.0001\end{array}$} \\
\hline & G.nut haulms & 3465.50 & $84.52^{\mathrm{ab}}$ & \\
\hline & Banana peels & 3954.50 & $96.451^{\mathrm{ab}}$ & \\
\hline & Sweet potato vines & 4810.00 & $117.32^{\mathrm{bc}}$ & \\
\hline & Maize stover & 6238.00 & $152.15^{\mathrm{c}}$ & \\
\hline \multirow{5}{*}{ Jinja } & G.nut haulms & 2790.00 & $69.75^{\mathrm{a}}$ & \multirow{5}{*}{$\begin{array}{c}\mathrm{X}^{2}=25.83 \\
\mathrm{df}=4 \\
\mathrm{p}=0.0001\end{array}$} \\
\hline & Sugar cane tops & 3468.00 & $86.7^{\mathrm{ab}}$ & \\
\hline & Banana peels & 4069.00 & $101.72^{\mathrm{abc}}$ & \\
\hline & Sweet potato vines & 4866.00 & $121.65^{\mathrm{bc}}$ & \\
\hline & Maize stover & 4907.00 & $122.67^{\mathrm{c}}$ & \\
\hline \multirow{5}{*}{ Buikwe } & Sugar cane tops & 3616.50 & $80.37^{\mathrm{a}}$ & \multirow{5}{*}{$\begin{array}{c}\mathrm{X}^{2}=54.71 \\
\mathrm{df}=4 \\
\mathrm{p}=0.0001\end{array}$} \\
\hline & Banana peels & 4020.00 & $89.33^{\mathrm{ab}}$ & \\
\hline & G.nut haulms & 4608.00 & $102.4^{\mathrm{ab}}$ & \\
\hline & Sweet potato vines & 5599.00 & $124.42^{\mathrm{b}}$ & \\
\hline & Maize stover & 7581.50 & $168.48^{\mathrm{c}}$ & \\
\hline
\end{tabular}

${ }^{\mathrm{ab}}$ Means in the same row and same district without common letter are different at $\mathrm{p}<0.05$. 


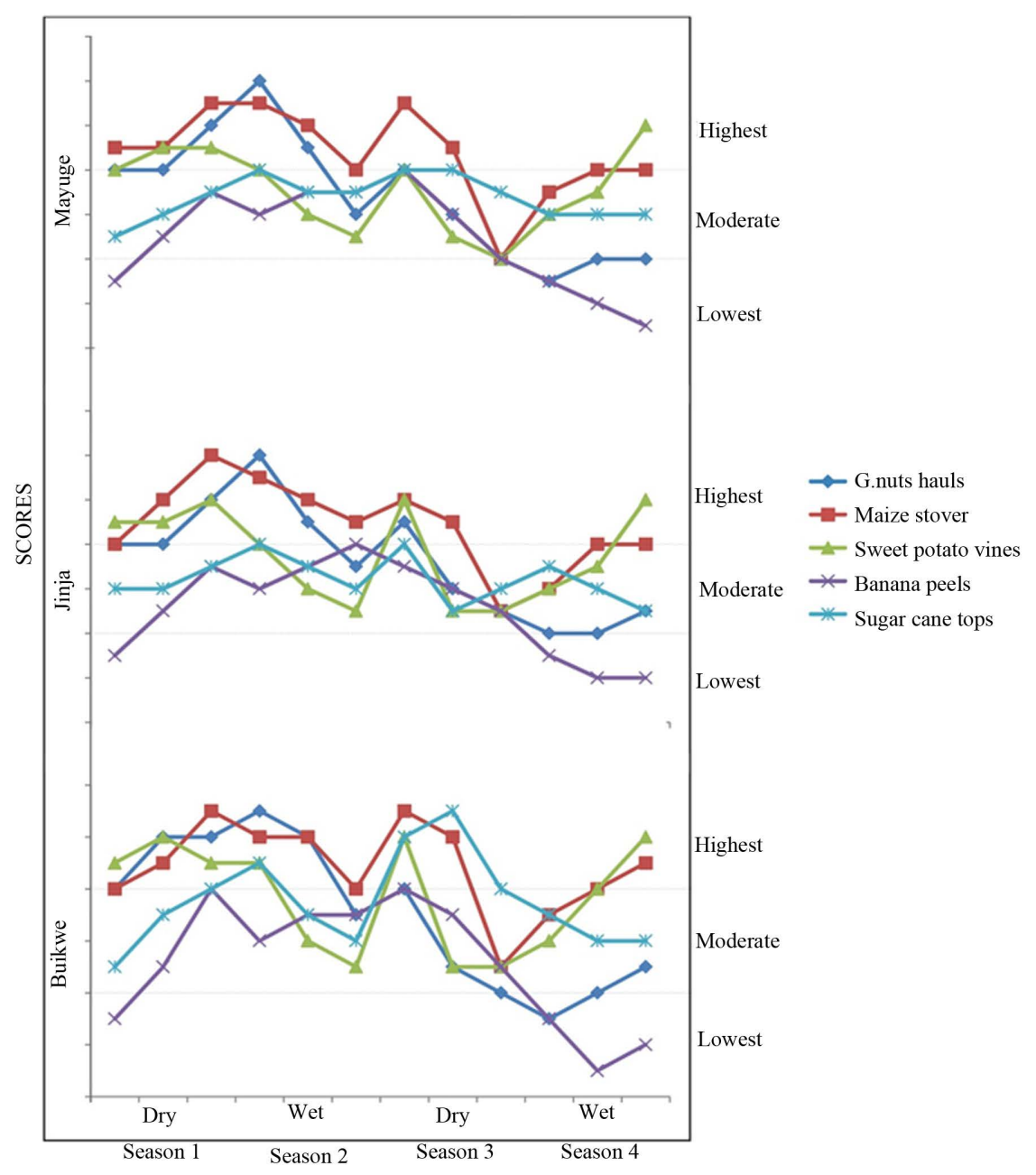

Figure 2. Spatial and temporal variability of crop residues in the study areas.

season. It was noted that most frequently utilized crop residues are highest in abundance in third season and lowest in fourth season. Maize stovers were highest in abundance in Jinja district in first season, while the rest of the districts hit their peak abundance in third season. Ground nuts haulms were moderately abundant in fourth season in Jinja district while in the rest of the districts it was lowest in fourth season.

\subsection{Methods Applied by Farmers to Store, Process and Preserve Crop Residues}

Table 3 shows different methods used by the farmers to store, process and preserve crop residues. It was depicted that storage, processing and preservation had positive effect on improving crop residues intake by the dairy cattle. Percentage of the respondents using different methods of storage, processing and preservation are shown in Table 2. The majority of the farmers $52.7 \%$ stored their maize stover by home heaps while $7.6 \%$ did not use any particular storage facilities. Physical processing (chopping) of maize stover, ground nuts haulms and sweet potato vines practiced by $71.2 \%, 60.4 \%$ and $88.3 \%$ of the respondents respectively was the most common technology applied. Farmers sprayed crop residues with additives that included molasses, salt, brewer's spent grain and yeast to improve on dry matter intake. The major preservation method of ground nuts haulms, sweet potato vines and banana peels was by drying represented by $3.6 \%, 27.9 \%$ and $44.1 \%$ respectively.

\subsection{Farmers' Rankings of Limitations to Utilization of Crop Residues}

The ranking of farmers on limitation to utilization of crop residues in smallholder dairy cattle feeds and feeding system are presented in Table 3. Kruskal-Wallis test revealed a high significant difference among the farmers 
Table 2. Methods applied by farmers to store, process and preserve crop residues.

\begin{tabular}{ccccccc}
\hline Practice & \multicolumn{6}{c}{ Percentage score of the farmers undertaking the method } \\
& Method & MS & GNH & SPV & SCT & BP \\
\hline Field heap & 22.3 & 24.1 & 2 & & \\
Storage & Home heaps & 52.7 & 36.3 & 45.2 & & 38.5 \\
& Communal shade & 17.4 & & 27.7 & & \\
& None & 7.6 & & 25.1 & & \\
Processing & Physical processing & 71.2 & 60.4 & 88.3 & & \\
& Spraying with additives & 81.1 & 21.6 & 2.7 & 5.8 & 27 \\
& None & 7.2 & 38.8 & 24.3 & 3.6 & 32.4 \\
& Drying & & 3.6 & 27.9 & & 44.1 \\
\hline & Multi-nutrient block & 2.4 & & 2.4 & & \\
\hline
\end{tabular}

MS = maize stover, GNH = ground nuts haulms, SPV = sweet potato vines, $\mathrm{SCT}=$ sugar cane tops, $\mathrm{BP}=$ banana peels, "With salt, molasses, and brewer’s grain/yeast.

Table 3. Farmers ranking of limitation to utilization of crop residues.

\begin{tabular}{|c|c|c|c|c|}
\hline District & Limitation & Sum of ranks & Mean of ranks & (Chi' ${ }^{2}$, df, p-value) \\
\hline \multirow{5}{*}{ Mayuge } & Limited labour & 1748.50 & $52.98^{\mathrm{a}}$ & \multirow{5}{*}{$\begin{array}{c}\mathrm{X}^{2}=58.67 \\
\mathrm{df}=4 \\
\mathrm{p}=0.0001\end{array}$} \\
\hline & Limited land & 1829.50 & $55.44^{\mathrm{a}}$ & \\
\hline & Transportation (Bulky) & 2268.00 & $84^{\mathrm{ab}}$ & \\
\hline & Lack of knowledge to preserve & 4583.00 & $111.78^{\mathrm{bc}}$ & \\
\hline & Lack of knowledge to process & 4971.00 & $121.24^{\mathrm{c}}$ & \\
\hline \multirow{5}{*}{ Jinja } & Limited labour & 1572.50 & $58.24^{\mathrm{a}}$ & \multirow{5}{*}{$\begin{array}{c}\mathrm{X}^{2}=12.84 \\
\mathrm{df}=4 \\
\mathrm{p}=0.012\end{array}$} \\
\hline & Limited land & 1639.00 & $63.04^{\mathrm{ab}}$ & \\
\hline & Transportation (Bulky) & 1458.50 & $66.30^{\mathrm{ab}}$ & \\
\hline & Lack of knowledge to preserve & 2764.50 & $83.77^{\mathrm{ab}}$ & \\
\hline & Lack of knowledge to process & 3443.50 & $88.29^{b}$ & \\
\hline \multirow{5}{*}{ Buikwe } & Transportation (Bulky) & 1858.00 & $59.94^{\mathrm{a}}$ & \multirow{5}{*}{$\begin{array}{c}\mathrm{X}^{2}=33.08 \\
\mathrm{df}=4 \\
\mathrm{p}=0.0001\end{array}$} \\
\hline & Limited labour & 2301.00 & $67.68^{\mathrm{a}}$ & \\
\hline & Limited land & 3262.50 & $95.96^{\mathrm{ab}}$ & \\
\hline & Lack of knowledge to process & 4910.50 & $111.60^{\mathrm{b}}$ & \\
\hline & Lack of knowledge to preserve & 4688.00 & $114.34^{\mathrm{b}}$ & \\
\hline
\end{tabular}

${ }^{\mathrm{a}}$ Means in the same row and same district without common letter are different at $\mathrm{p}<0.05$.

ranking. Buikwe district ranked lack of knowledge to preserve crop residue (mean of ranks $=114.32$ ) as the major limitation in utilization of crop residues. While in Jinja and Mayuge district lack of knowledge to process crop residues (mean rank $=88.29,121.24$ ) was ranked as the major limitation to utilization. Other limiting factors ranked in descending order of importance were: limited land, transportation of crop residues from the field and limited labour. 


\section{Discussion}

Crop residues are fibrous parts of crops that remain after those edible to human beings have been removed. Through their digestive adaptations, primarily based on the degradation of fibrous materials by microbes in the rumen [15], ruminant animals have the unique capacity to utilize these otherwise useless by-products. This indicates that in dairy cattle feeding system, crop residues can replace roughages in rations, reducing the competition on cereals between human beings, monogastic and ruminant animals. Crop residues are readily available in LVZ, cheap feed resource because the grain which is the main marketable product takes care of the production costs.

The major crop residues available in the study areas were established as maize stover, sweet potato vines, sugar cane tops, ground nuts haulms and banana peels. Maize stover was ranked a major crop residue available and utilizable in smallholder dairy farming system in LVZ of Uganda, the study area. It was also established that with increased crop failures due to prolonged drought, as has become more frequent even in the LVZ large acreages of maize crops would be available for conversion into feed for smallholder dairy farms. Uganda currently ranks with the highest potential of maize production for export among the countries in the East, Central and Southern African region where maize is the staple food [17]. If this potential is exploited, the massive quantities of maize stover generated will be a major feed resource for smallholder dairy farmers. Furthermore, rankings of spatial and temporal variability of crop residues indicate that first season (December to February) was the main harvest period, which explained the abundance of the crop residues in second season (March to May). This is in line with studies by [11] who noted that variations in availability of crop residues as major factors constraining their utilization. Furthermore, suggesting that interventions to enhance utilization of crop residues in LVZ should prioritize maize stover. However, its nutritive value is low [14] [18], research should be directed towards enhancing its crude protein content, improving its digestibility and reduction on its crude fibre.

While there are prospects to improve the nutritive value of crop residues in LVZ through supplementation, simple treatment, processing and preservation methods, maize stover and sweet potato vain were fed without much attention to improve their nutritive values. The only method undertaken by number of respondents ( $71.2 \%$ maize stover and $88.3 \%$ sweet potato vain) was physical processing (Chopping). Feeding crop residues when they are unprocessed or untreated limits their intake [19]. Integrating crop residues with forage legumes improves rumen microbial degradation of crop residues by supplying nitrogen to the rumen microbes which increases digestibility and intake of poor quality feed [20]. Nitrogen supplementation in the rumen environment deficient of nitrogen leads to increased dry matter digestibility and voluntary feed intake [21]. Furthermore, feeding small amounts of naturally occurring high protein supplement such as brewers spent grain also improves the nutritive value of crop residues [22]. Biological treatment of maize stover utilizing mushroom fungi through fermentation, is another alternative to convert maize straw into high nutritive value dairy cattle feed [18].

Maintaining access to sufficient quality and quantity of nutrition is vital for milk production in the dairy cattle [19]. Although crop residues are important feed resources they are low in nutritive value [11] and poor storage methods (Table 2) practiced by farmers predisposes them to rain and sunlight resulting into further deterioration in quality [14]. Majority of the farmers (92.4\%) interviewed stored maize stovers for future use in dairy cattle feeding. Although the majority of the farmers understood very well the importance of storage and tried to practice it but it was established that large proportion was left in the field for the animals to graze in situ hence resulting into inefficient utilization. Besides, where the crop residues were stored, during feeding, it was thrown in the cattle boma. This resulted into trampling and wastage. It was further observed that crop residues especially maize stovers are left to stand in the field post-harvest where they lose leaves prior to being harvested for storage. Even following harvesting and stacking they tend to be stored outdoors in home heaps as reported by $52.7 \%$ of the respondents resulting into further nutrient losses through leaching. These findings are consistent with earlier studies that mentioned low nutritive value of crop residues [11] and poor handling of maize stovers [18]. Therefore, in order to improve utilization of maize stover, the challenges on handling during harvesting, process and storage should be addressed. This is vital in enhancing maize stover utilization and improving its intake and nutritive value for improved smallholder dairy farm productivity.

Results of this study further reveals that inadequate knowledge to process and preserve crop residues was major limitations in utilization of crop residues. Other limitations in descending order included; difficulty in transportation (bulkiness), seasonal variability, labour and storage facilitates. Similar findings were reported by [13] who cited lack of knowledge and capital, [23] high labour cost, [24] low nutritive value and [12] difficulty 
in transportation because crop residues are bulky. All these limitation directly influence the stability of the nutritive values of crop residues and hence there utilization. Earlier research interventions for promoting smallholder dairy cattle productivity focused on fodder agronomy and seed production [8]. However, with increased effects of climate change and reducing household land holdings, emphasis must be shifted to utilization crop residues. But nutritional deficiencies of crop residues make them unable to support maintenance and production requirements of a milking dairy cows [15], pointing to the need for evaluation of strategic processing and supplementation with locally available ingredients as a viable research interventions [25]. This calls for research innovations to improve on processing, preservation and storage of crop residues, which should be appealing to smallholder dairy cattle farmers for sustainable productivity.

\section{Conclusion and Recommendations}

Maize stover and sweet potato vines were the major crop residues utilized in the study area. They were not utilized at the optimum period thus compromising on their quality and variability. Lack of knowledge, poor quality and transportation were the major limitations. Improving productivity in dairy cattle production system in LVZ should therefore target qualitative improvement of nutritive value of maize stover. Research thrust should be directed towards nutritive value improvement techniques both on station and on farm to justify the economic feasibility. Biological processing of maize stovers with mushroom fungi may provide a feasible research notion for improved utilization of maize stover in order to improved smallholder dairy cattle productivity.

\section{Acknowledgements}

We are grateful to East African Agricultural Productivity Project (EAAPP) Uganda for funding this study. We are also thankful to the Director National Livestock Resources Research Institute for facilitating the smooth implementation of the project activities.

\section{References}

[1] Kabirizi, J., Mpairwe, D. and Mutetikka, D. (2006) Improving Dairy Cattle Productivity in Smallholder Farms in Uganda: Incorporating Leguminous Forages in Farming Systems. Uganda Journal of Agricultural Sciences, 12, 1-12.

[2] Winrock International (1992) Assessment of Animal Agriculture in Sub-Saharan Africa. Winrock International Institute for Agricultural Development, Morrilton.

[3] Kabi, F. and Bareeba, F.B. (2007) Factors Influencing Adoption of Cattle Excreta Management Practices for Improved Elephant Grass (Pennisetum purpureum) Production by Elephant Grass (Pennisetum purpureum) Production by Smallholder Dairy Farmers. Livestock Research for Rural Development, 19, Article \#24.

[4] MAAIF (2010) Agriculture for Food and Income Security: Agricultural Sector Development Strategy and Investment Plan 2010/11-2014/15. MAAIF, Entebbe, Uganda.

[5] FAO (2012) Crop Residue Based Densified Total Mixed Ration—A User-Friendly Approach to Utilise Food Crop ByProducts for Ruminant Production, by Walli, T.K., Garg, M.R. and Makkar, H.P.S., FAO Animal Production and Health Paper, No. 172, Rome.

[6] Bahiigwa, G., Rigby, D. and Woodhouse, P. (2005) Right Target, Wrong Mechanism? Agricultural Modernization and Poverty Reduction in Uganda. World Development, 33, 481-496. http://dx.doi.org/10.1016/j.worlddev.2004.09.008

[7] UBOS (2012) Uganda Bureau of Statistics, Statistical Abstract. www.ubos.org

[8] Mugerwa, S., Kabirizi, J.M., Zziwa, E. and Lukwago, G. (2012) Utilization of Crop Residues and Agro-Industrial ByProducts in Livestock Feeds and Feeding Systems of Uganda. International Journal of Biosciences, 2, 82-89.

[9] Lentes, P., Holmann, F., Peters, M. and White, D. (2010) Constraints, Feeding Strategies and Opportunities to Improve Productivity and Income in Milk Production Systems in Olancho, Honduras. Tropical Grasslands, 44, 33-46.

[10] Tesfaye, A. and Chairatanayuth, P. (2007) Management and Feeding Systems of Crop Residues: The Experience of East Shoa Zone, Ethiopia. Livestock Research for Rural Development, 19, Article \#31.

[11] Tsopito, C.M. (2003) Crop Residues as a Feed Source for Ruminants. UNISWA Journal of Agriculture, 12, $29-34$.

[12] Walli, T.K. (2009) Crop Residue Based Densified Feed Block Technology for Improving Ruminant Productivity. In: Walli, T.K., Ed., Compendium, Satellite Symposium on Fodder Block Technology, New Delhi, 67-73.

[13] Anandan, S., Khan, A.A., Ravi, D., Reddy, J. and Blummel, M. (2010) A Comparison of Sorghum Stover Based Complete Feed Blocks with a Conventional Feeding Practice in Peri-Urban Dairy Cattle. Animal Nutrition and Feed Tech- 
nology, 10, 23-28.

[14] Njarui, D.M.G., Gatheru, M., Wambua, J.M., Nguluu, S.N., Mwangi, D.M. and Keya, G.A. (2011) Feeding Management for Dairy Cattle in Smallholder Farming Systems of Semi-Arid Tropical Kenya. Livestock Research for Rural Development, 23, Article \#111.

[15] Preston, T.R. and Leng, R.A. (1987) Matching Ruminant Production Systems with Available Resources in the Tropics and Subtropics. Penambul Books, Armidale, 259 p. http://www.utafoundation.org/P\&L/preston\&leng.htm

[16] XLSTAT (2013) http://wwwaddinsoft.com

[17] Okaboi, G. (2011) Improved Input Use, Productivity and Commercialization in Uganda Maize Production. PhD Thesis, Makerere University, Kampala, 151.

[18] Akinfemi, A., Adu, O.A. and Adebiyi, O.A. (2009) Use of White Rot-Fungi in Upgrading Maize Straw and, the Resulting Impact on Chemical Composition and in Vitro Digestibility. Livestock Research for Rural Development, 21, Article \#162.

[19] Lukuyu, B., Franzel, S., Ongadi, P.M. and Duncan, A.J. (2011) Livestock Feed Resources: Current Production and Management Practices in central and Northern Rift Valley Provinces of Kenya. Livestock Research for Rural Development, 23, Article \#112.

[20] Smith, O.B. (1993) Feed Resources for Intensive Smallholder Systems in the Tropics: The Role of Crop Residues. Proceedings of the XVII International Grassland Congress, 18-21 February 1993, Rockhampton.

[21] Mlay, P.S., Pereka, A.E., Balthazary, S.T., Phiri, E.C.J., Hvelplund, T., Weisbjerg, M.R. and Madsen, J. (2005) The Effect of Maize Bran or Maize Bran Mixed with Sunflower Cake on the Performance of Smallholder Dairy Cows in Urban and Peri-Urban Area in Morogoro, Tanzania. Livestock Research for Rural Development, 17, Art. \#2.

[22] NRC (2001) Nutrient Requirements of Dairy Cattle. 7th Revised Edition, National Research Council, National Academy Press, Washington DC.

[23] Dejene, M., Bediye, S., Kehaliw, A., Kitaw, G. and Nesha, K. (2009) On-Farm Evaluation of Lactating Crossbred (Bos taurus x Bos indicus) Dairy Cows Fed a Basal Diet of Urea Treated Teff (Eragrostis tef) Straw Supplemented with Escape Protein Source during the Dry Season in Crop-Livestock Production System of North Shoa, Ethiopia. Livestock Research for Rural Development, 21, Article \#61.

[24] Ngongoni, N.T., Mapiye, C., Mwale, M. and Mupeta, B. (2006) Factors Affecting Milk Production in the Smallholder Dairy Sector of Zimbabwe. Livestock Research for Rural Development, 18, Article \#72.

[25] Mubiru, S.I., Tenywa, J.S., Halberg, N., Romney, D., Nanyeenya, W., Baltenweck, I. and Staal, S. (2007) Categorization of Dairy Production Systems: A Strategy for Targeting Meaningful Development of the Systems in Uganda. Livestock Research for Rural Development, 19, Article \#100. 